\title{
Plasma-membrane ATPase action affects several stress tolerances of Saccharomyces cerevisiae and Schizosaccharomyces pombe as well as the extent and duration of the heat shock response
}

\author{
Barry Panaretou and Peter W. Piper* \\ Department of Biochemistry, University College London, London WC1E 6BT, UK
}

(Received 2 January 1990; revised 17 April 1990; accepted 4 May 1990)

\begin{abstract}
The pmal.1 mutations of Saccharomyces cerevisiae and Schizosaccharomyces pombe decrease plasma-membrane ATPase activity. This study investigated how they affect different stress tolerances, and the extent and duration of the heat-shock response. pma1.1 mutants exhibited higher resistance to ethanol and osmotic stress, but lower tolerance to ultraviolet damage, as compared to wild-type cells. pma1.1 mutations also increased tolerance of the lethal temperature of $48^{\circ} \mathrm{C}$ in cells in which no heat-shock response had been induced. However, after induction of a heat-shock response and elevated thermotolerance by a $25-38{ }^{\circ} \mathrm{C}$ upshift, then maintaining cells at $38{ }^{\circ} \mathrm{C}$ for $40 \mathrm{~min}$, pmal.1 lowered subsequent tolerances of much higher lethal temperatures. Analysis of pulse-labelled $S$. cerevisiae proteins revealed reduced heat-shock protein synthesis in the pma1.1 mutant after a $25-38{ }^{\circ} \mathrm{C}$ heat shock. This may explain the greater increases in thermotolerance in wild-type as compared to pma1.1 cells after both were given identical $25-38{ }^{\circ} \mathrm{C}$ shocks. With more severe treatment $\left(25-42{ }^{\circ} \mathrm{C}\right)$, heat-shock protein synthesis in wild-type cells, although initially high, was switched off more rapidly than in the pma1.1 mutant. These results indicate that plasma-membrane ATPase action exerts a major influence over several stress tolerances, as well as the extent and duration of heat-shock protein synthesis following induction of the heat-shock response.
\end{abstract}

\section{Introduction}

The ability of organisms to withstand cytotoxic agents or stressful situations is intimately affected both by their physiological state and by their capacity to induce protective responses. One of the best-characterized stress-induced responses is that elicited by heat shock. This 'heat shock response' (reviewed by Craig, 1986; Lindquist \& Craig, 1988) entails the transient induction of a small number of heat-shock proteins (HSPs), and a simultaneous blocking of the synthesis of most of the proteins made prior to the shock. One of its most marked consequences is an increase in thermotolerance, measured as the ability to withstand normally lethal temperatures. A heat-shock response is displayed by most organisms and many of the induced genes show a remarkable degree of evolutionary conservation. Although experimentally the response is usually induced by temperature upshift, several potentially cytotoxic chemicals are also potent inducers. All these inducers may act through a common trigger, possibly the intracellular

Abbreviation: HSPs, heat-shock proteins. accumulation of aberrant or misfolded protein (Ananthan et al., 1986; Pelham, 1987).

Stress tolerances can be affected by many factors in addition to the actions of those proteins induced through the triggering of a stress response. Thus thermotolerance in Saccharomyces cerevisiae cannot be attributed solely to the actions of HSPs. It is also affected by growth state, being lowest in cells in rapid exponential growth and high in stationary-phase $\left(\mathrm{G}_{0}\right)$ cells (Iida \& Yahara, 1984; Iida, 1988). The high thermotolerance of $G_{0}$ cells may be due in part to the induction of HSP genes with the decline in cyclic AMP levels as cells enter stationary phase (Boucherie, 1985; Iida \& Yahara, 1984; Shin et al., 1987). A few of the proteins made in heat-shocked $S$. cerevisiae correspond to glycolytic enzymes that are also made by unstressed cells (Piper et al., 1986, 1988). Furthermore, we recently identified the gene for plasma membrane ATPase (PMAI) as one of the few in $S$. cerevisiae still efficiently transcribed after heat shock to $42{ }^{\circ} \mathrm{C}$, approximately $3{ }^{\circ} \mathrm{C}$ above the maximum growth temperature. Polyadenylated RNA pulse-labelled in vivo at $42{ }^{\circ} \mathrm{C}$ hybridizes to relatively few yeast sequences, one of them being the PMAl transcribed region (Curran et 
al., 1988). This led us to investigate mutants altered in plasma-membrane ATPase activity to obtain evidence of whether the activity of this important enzyme is a major determinant of the tolerances of budding ( $S$. cerevisiae) and fission (Schizosaccharomyces pombe) yeast to heat shock and other stresses.

Plasma-membrane ATPase is an electrogenic proton pump crucial to all fungal and plant cells. It generates the electrochemical $\mathrm{H}^{+}$gradient essential for such important cellular functions as the secretion of acids, the uptake of nutrients, the maintenance of $\mathrm{K}^{+}$levels and the regulation of intracellular $\mathrm{pH}$ (Ulaszewski et al., 1983, 1987; Serrano et al., 1986; Eraso et al., 1987; Eraso \& Gancedo, 1987). One of the effects of heat-shock stress, at least in $S$. cerevisiae (Weitzel et al., 1987), is a dissipation of this $\mathrm{H}^{+}$gradient. The resultant cytoplasmic acidification should be counteracted by plasmamembrane ATPase action, even though this enzyme has not previously been considered a possible influence on the tolerances or responses of fungi and plants to heat shock.

The plasma-membrane ATPases of Neurospora crassa, $S$. cerevisiae and Sch. pombe all display extensive sequence homology, as well as similar hydrophobicity profiles, thought to indicate 8-10 transmembrane domains (Aaronson et al., 1988). Plasma-membrane ATPases from flowering plants also have up to $36 \%$ amino acid sequence homology with these fungal enzymes (Harper et al., 1989; Pardo \& Serrano, 1989; Boutry et al., 1989). This ATPase is so conserved in structure and function that should it be shown to influence stress tolerances in one organism, there would be grounds to suspect that its action might also determine tolerance levels in diverse fungi and plants.

\section{Methods}

Strains. The $S$. cerevisiae pmal.1, pma1.2, pmal.3 and pmal.4 mutants (strains MG2129, MG2130, MG2131 and MG2132 respectively), their $\mathrm{PMAl}^{+}$prototrophic parent $\varepsilon 1278 \mathrm{~b}$ (Ulaszewski et al., 1983), the Sch. pombe strain Jv66 ( $\mathrm{h}^{-}$pmal.1, ade-413) and its parent strain $972\left(\mathrm{~h}^{-}\right.$ade-413) (Ulaszewski et al., 1986) were all kindly provided by A. Goffeau (University of Louvain, Belgium).

Media. All tolerance experiments were done on cells that had been maintained in exponential growth at $25^{\circ} \mathrm{C}$ on YEPD medium $(2 \%$ bactopeptone, $1 \%$ yeast extract, $2 \%$ glucose, all $\mathrm{w} / \mathrm{v}$ ) for more than 50 generations. Just prior to each experiment, $S$. cerevisiae cultures were briefly sonicated, just sufficiently for no cell aggregates to be seen by light microscopy. With the Sch. pombe cultures this sonication step was unnecessary.

Determinaton of killing kinetics. Thermotolerance experiments were done on exponential (0.5-1 $\times 10^{7}$ cells ml $\left.{ }^{-1}\right)$ YEPD cultures. The nonacute heat-shock treatment used for induction of thermotolerance was a rapid shift of part of each culture (the 'induced' cells) from $25^{\circ} \mathrm{C}$ to $38^{\circ} \mathrm{C}$, maintaining cultures at $38^{\circ} \mathrm{C}$ for $40 \mathrm{~min}$ prior to an immediate shift to $52^{\circ} \mathrm{C}$ for a variable period. An identical portion of each culture (the cells 'uninduced' for thermotolerance) was immediately transferred from $25^{\circ} \mathrm{C}$ to $48^{\circ} \mathrm{C}$ for variable times, killing of these cells at temperatures higher than $48^{\circ} \mathrm{C}$ being too rapid for accurate measurement. At intervals from 0 to $15 \mathrm{~min}$, while cultures were at $48^{\circ} \mathrm{C}$ or $52{ }^{\circ} \mathrm{C}$, aliquots were rapidly diluted into $5 \mathrm{ml}$ YEPD at room temperature $\left(21-23^{\circ} \mathrm{C}\right)$ and cells plated on YEPD plates within $20 \mathrm{~min}$ of the exposure to high temperature.

For measurements of ultraviolet killing, cells were diluted appropriately in YEPD and $0.15 \mathrm{ml}$ aliquots spread on YEPD plates to give 300 cells per plate. Immediately after plating, the cells were exposed to an ultraviolet light source for various times.

To measure tolerance of high ethanol or salt concentrations, cells in exponential growth at $25^{\circ} \mathrm{C}$ on YEPD $\left(0.5-1 \times 10^{7}\right.$ cells ml-1) were diluted appropriately in YEPD at $25^{\circ} \mathrm{C}$ and additions made of either absolute ethanol or $4 \mathrm{M}-\mathrm{NaCl}$ (to final concentrations of $12.5 \%, \mathrm{v} / \mathrm{v}$, and $2.5 \mathrm{M}$ respectively). Aliquots of $0.1 \mathrm{ml}$ were removed immediately (for the zero time point) and at subsequent intervals, these being immediately diluted 100 - to 1000 -fold in YEPD prior to plating on YEPD plates.

In all of these experiments, killing was measured from the colonies (including petites) on YEPD plates incubated at $28^{\circ} \mathrm{C}$. Each experiment was repeated at least five times, with similar results, each survival shown in Figs. 1,2 and 4 being the results from a representative experiment. Since each time point involved the counting of at least 300 colonies the major error in these viability measurements was in the preparation of serial dilutions. This error was estimated as no more than $15 \%$.

Pulse labelling of S. cerevisiae proteins during heat shock. From $1 \times 10^{8}$ to $2 \times 10^{8}$ cells from exponential YEPD cultures of $S$. cerevisiae $\varepsilon 1278 \mathrm{~b}$ and MG2129 were collected by centrifugation $(3000 \mathrm{~g}$ for $5 \mathrm{~min}$ ), resuspended in $20 \mathrm{ml} \mathrm{CMD} \mathrm{medium} \mathrm{at} 25^{\circ} \mathrm{C} \mathrm{(2 \%} \mathrm{glucose,} 0.67 \%$ yeast nitrogen base without amino acids), recentrifuged, resuspended in $20 \mathrm{ml} \mathrm{CMD} \mathrm{medium} \mathrm{and} \mathrm{incubated} \mathrm{for} 20 \mathrm{~min}$ at $25^{\circ} \mathrm{C}$ prior to heat shock. During this $20 \mathrm{~min}$ period the cultures were subdivided into $1 \mathrm{ml}$ aliquots in glass tubes. To heat shock the cells, aliquots were shifted to either $38^{\circ} \mathrm{C}$ (Fig. $3 a$ ) or $42^{\circ} \mathrm{C}$ (Fig. $3 b$ ) and, at variable times after this temperature upshift, were labelled with $\left[{ }^{35} \mathrm{~S}\right]$ methionine $\left(10 \mu \mathrm{Ci} \mathrm{ml}^{-1}\right.$; $370 \mathrm{kBq} \mathrm{ml}^{-1}$ ). Each pulse-labelling was for $15 \mathrm{~min}$. A control $1 \mathrm{ml}$ aliquot was pulse-labelled for $1 \mathrm{~h}$ at $25^{\circ} \mathrm{C}$ without any heat shock. The cells from each labelling were rapidly chilled, then used in the preparation of samples of total cell protein which were analysed on one dimensional $12.5 \%$ polyacrylamide gels as described by Piper et al. (1986).

\section{Results}

\section{Influence of the pmal.1 mutations of S. cerevisiae and} Sch. pombe on thermotolerance

When $S$. cerevisiae or Sch. pombe cells in exponential growth at $25^{\circ} \mathrm{C}$ are placed at $48{ }^{\circ} \mathrm{C}$ they rapidly lose viability. Neither organism can synthesize HSPs above $42-43^{\circ} \mathrm{C}$ (see Discussion). In both species, pmal.1 caused higher thermotolerance levels at $48^{\circ} \mathrm{C}$, as manifested by the slightly greater survival of mutant as compared to wild-type cells in Figs $1(a)$ and 2(a). Similar results were obtained with $S$. cerevisiae pmal.2, pmal.3 and pma1.4 (data not shown). If, prior to exposure to lethal temperatures, the $S$. cerevisiae or Sch. pombe 

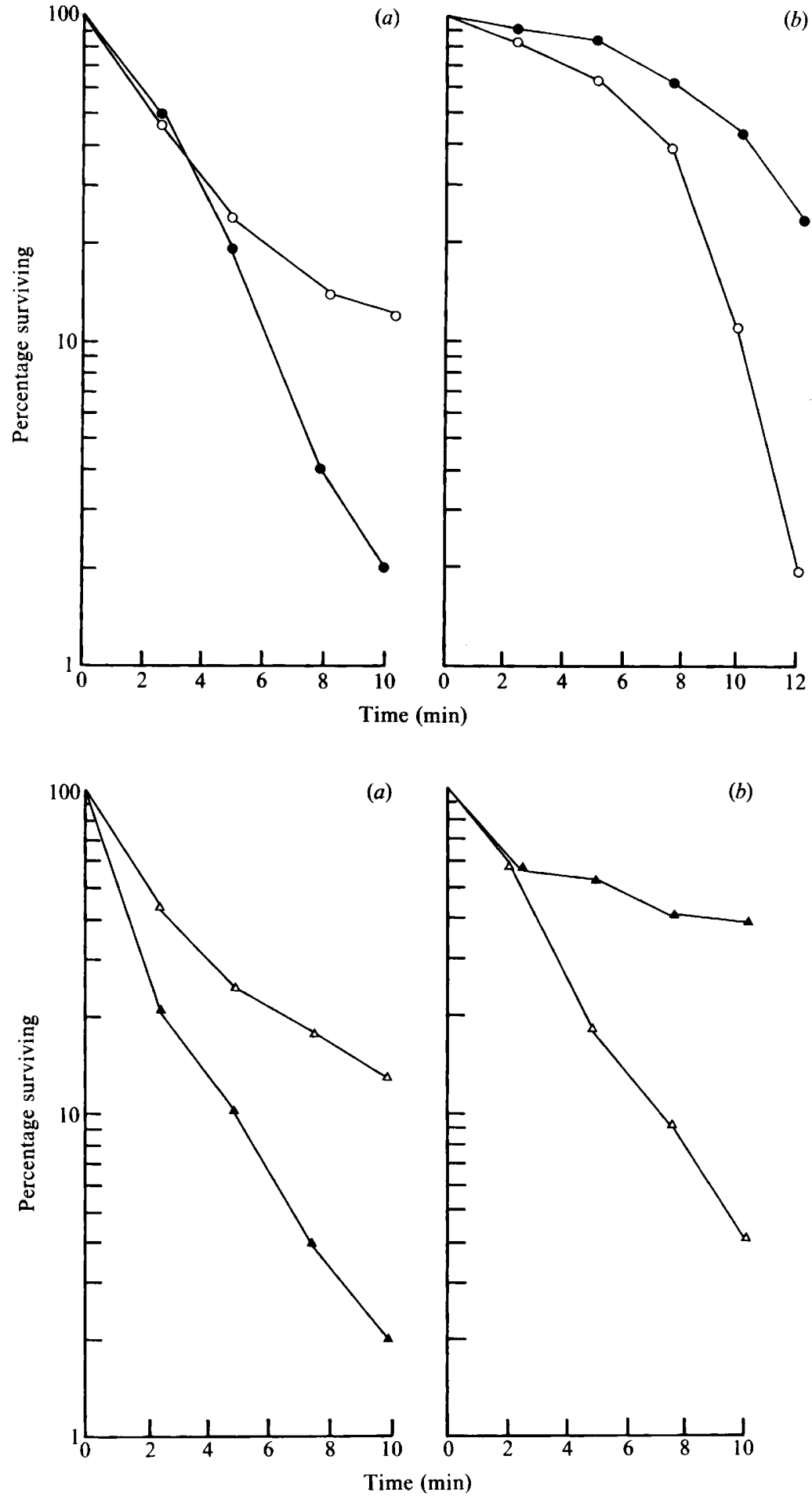

Fig. 1. High temperature tolerance of the $S$. cerevisiae pmal.1 mutant (strain MG2129) (O) and its wild-type parent $(\varepsilon 1278 \mathrm{~b})(O)$. Cultures were either (a) uninduced for thermotolerance, being shifted to $48^{\circ} \mathrm{C}$ from $25^{\circ} \mathrm{C}$; or $(b)$ had their thermotolerance elevated by prior heat shock from $25^{\circ} \mathrm{C}$ to $38^{\circ} \mathrm{C}$ for $40 \mathrm{~min}$ before being shifted to $52^{\circ} \mathrm{C}$.

Fig. 2. High temperature tolerance of the Sch. pombe pmal.I mutant (strain JV66) $\triangle$ ) and its wild-type parent $(972)(\Lambda)$. Cultures were either $(a)$ uninduced for thermotolerance, being shifted to $48^{\circ} \mathrm{C}$ from $25^{\circ} \mathrm{C}$; or $(b)$ had their thermotolerance elevated by prior heat shock from $25^{\circ} \mathrm{C}$ to $38^{\circ} \mathrm{C}$ for $40 \mathrm{~min}$ before being shifted to $52^{\circ} \mathrm{C}$.

cultures were given a non-acute heat shock $\left(25-38^{\circ} \mathrm{C}\right.$ temperature upshift then a $40 \mathrm{~min}$ incubation at $38^{\circ} \mathrm{C}$ ) this effect of pmal.1 on thermotolerance was reversed (Figs $1 b$ and $2 b$ ). This effect was also demonstrated with S. cerevisiae pma1.2, pma1.3 and pma1.4 (not shown). The non-acute heat shock to $38^{\circ} \mathrm{C}$ enables the induction of HSPs, associated with a marked elevation of thermo- tolerance (see Introduction). In both $S$. cerevisiae and Sch. pombe cells induced for this heat-shock response, pmal.1 reduced viability at high temperature. Comparison of Fig. $1(a)$ with Fig. $1(b)$, and of Fig. 2(a) with Fig. $2(b)$, reveals that pmal.1 reduces the increase in thermotolerance as the heat-shock response is induced by a $25-$ $38^{\circ} \mathrm{C}$ upshift. 

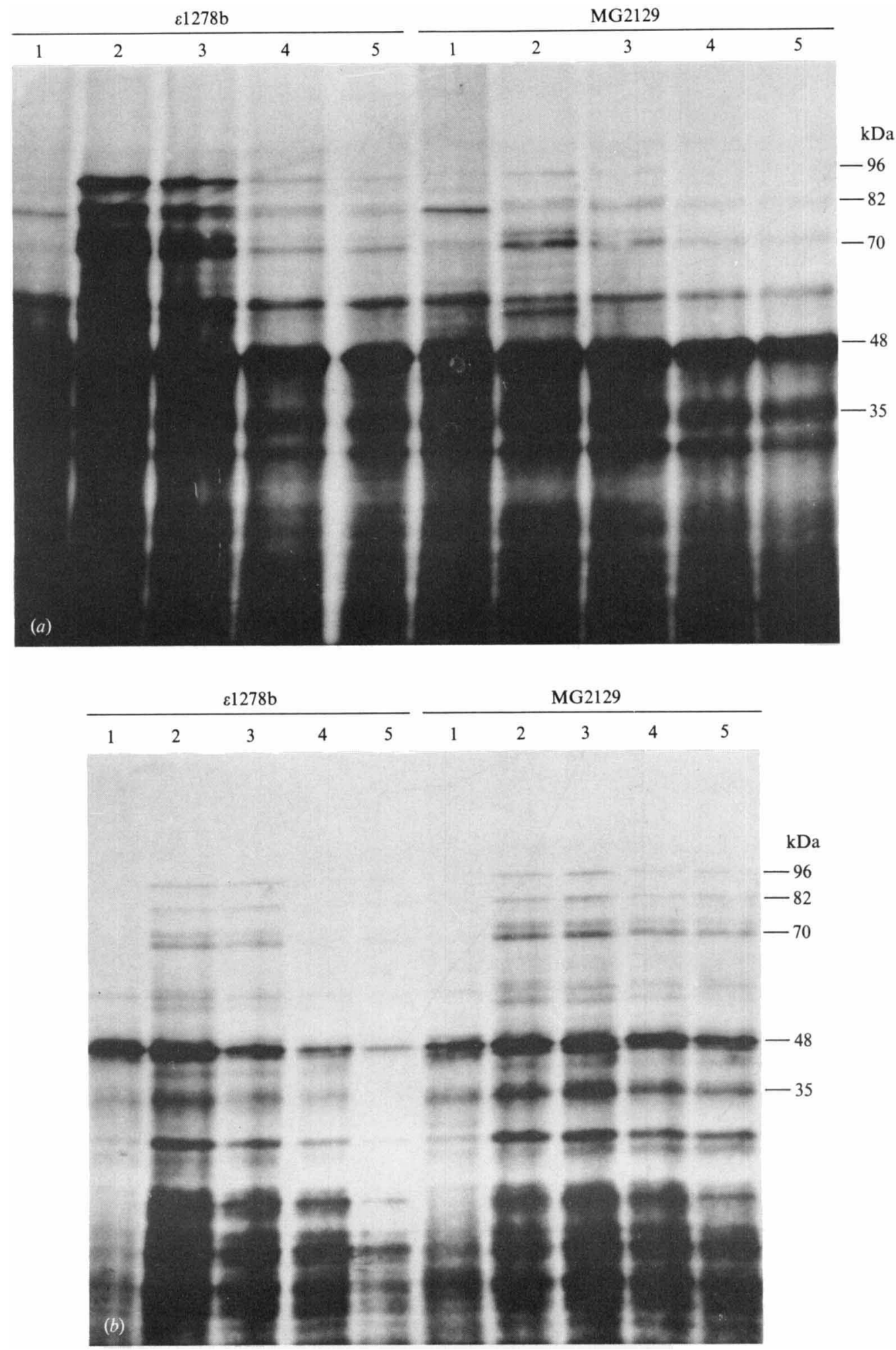

Fig. 3. Proteins pulse-labelled in heat-shocked cells of S. cerevisiae $\varepsilon 1278 \mathrm{~b}$ and pma1.1 mutant MG2129 after heat shock either to $38{ }^{\circ} \mathrm{C}$ (a); or to $42{ }^{\circ} \mathrm{C}(b)$. Cells were pulse-labelled with $\left[{ }^{35} \mathrm{~S}\right]$ methionine $10-25 \mathrm{~min}(2), 25-40 \mathrm{~min}(3), 40-55 \mathrm{~min}(4)$, or $55-70 \mathrm{~min}(5)$ after temperature upshift. Track 1 shows proteins labelled in unstressed cells at $25^{\circ} \mathrm{C}$. All gel samples contained protein from the same number of cells so the relative intensity of bands on the autoradiographs indicates relative protein labelling under these conditions. The indicated bands of 70, 82 and $96 \mathrm{kDa}$ are the large heat-shock proteins HSP70, HSP82 and HSP96. 

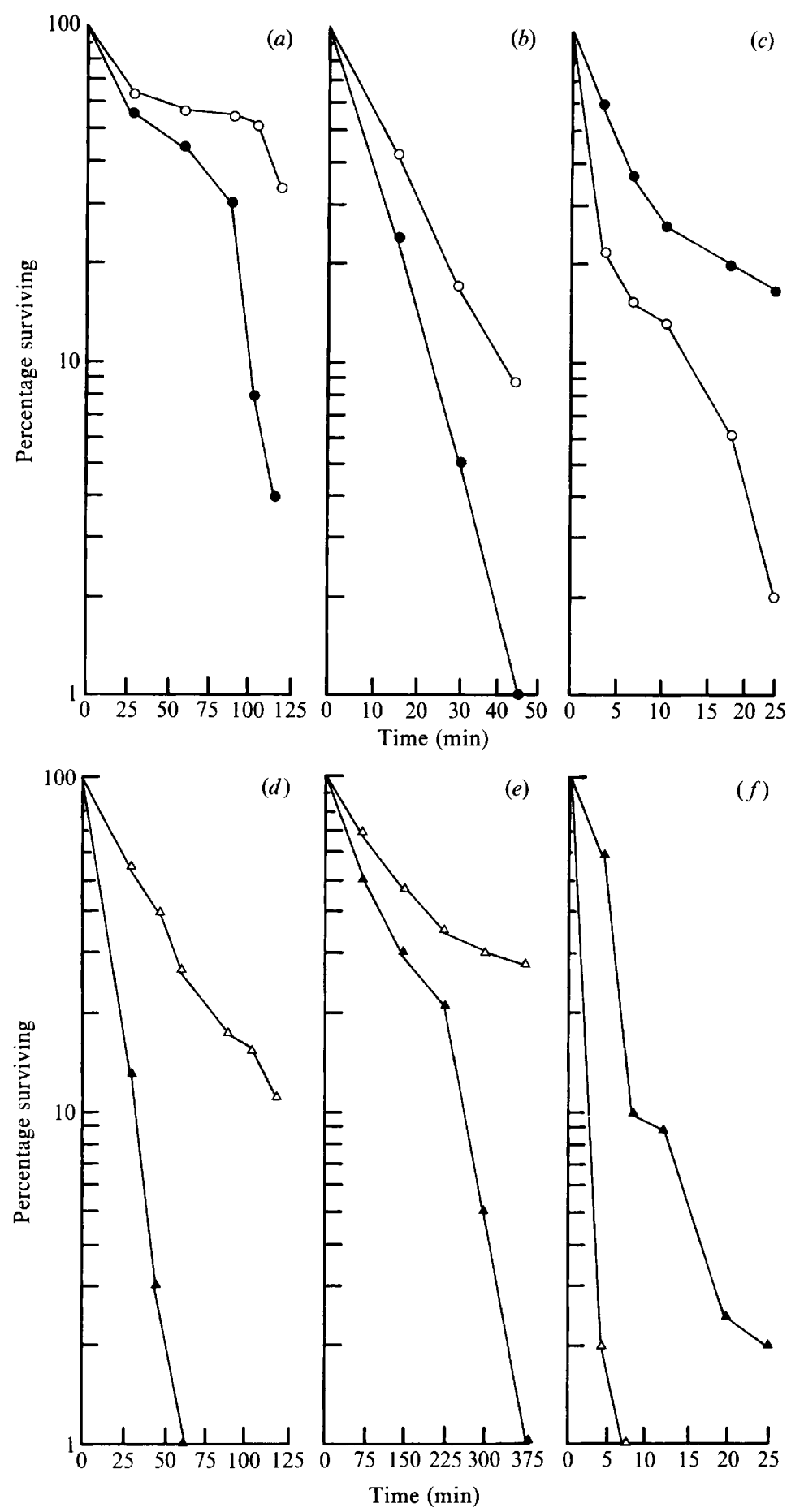

Fig. 4. Survival of yeast exposed to $(a, d) 12.5 \%(\mathrm{v} / \mathrm{v})$ ethanol; $(b, e) 2.5 \mathrm{M}-\mathrm{NaCl} ;$ and $(c, f)$ ultraviolet irradiation. $(a-c)$ Survival data for $S$. cerevisiae $\varepsilon 1278 \mathrm{~b}(\bigcirc)$ and pma1.1 mutant MG2129 (O); $(d-f)$ data for Sch. pombe $972(\triangle)$ and pmal.1 mutant JV66 $(\triangle)$.

\section{Influence of pma1.1 on HSP synthesis in S. cerevisiae}

S. cerevisiae $\varepsilon 1278 \mathrm{~b}$ and MG2129 were labelled with $\left[{ }^{35} \mathrm{~S}\right]$ methionine both before, and at intervals after, a 25 $38^{\circ} \mathrm{C}$ heat shock. Their labelled proteins were then separated on a one-dimensional gel (Fig. $3 a$ ). After this relatively mild heat shock $\left(38^{\circ} \mathrm{C}\right.$ is below the maximum growth temperature on glucose media), cells resumed an almost normal pattern of protein synthesis within about $1 \mathrm{~h}$ (Fig. 3a). However, synthesis of the major HSPs was dramatically reduced in the pmal.1 mutant strain. Therefore a partial suppression of the heat-shock 
response in mutant, compared to wild-type, cells is the probable reason for the lowered induction of thermotolerance by $25-38^{\circ} \mathrm{C}$ heat shock in pma1.1 S. cerevisiae (Fig. 1).

When this labelling was repeated under conditions of considerably more severe $\left(25-42^{\circ} \mathrm{C}\right)$ heat shock a rather different result was obtained (Fig. $3 b$ ). The temperature of $42^{\circ} \mathrm{C}$ is about $3{ }^{\circ} \mathrm{C}$ above the maximum for growth, and close to the maximum temperature at which $S$. cerevisiae will still display synthesis of HSPs (Piper et al., $1986,1988)$. Normally, after cells are shifted to $42{ }^{\circ} \mathrm{C}$, an initial 'burst' of HSP synthesis is followed by a progressive cessation of all protein synthesis over about $1 \mathrm{~h}$. This is apparent from the labelling of $S$. cerevisiae $\varepsilon 1278 \mathrm{~b}$ in Fig. $3(b)$. HSP synthesis in the pmal.1 mutant at $42^{\circ} \mathrm{C}$, although initially similar to that of wild-type cells, was not subject to such rapid inhibition and was sustained for at least $70 \mathrm{~min}$ at $42^{\circ} \mathrm{C}$ (Fig. 3 b).

These experiments indicate that, depending on the severity of the heat shock, pmal.1 can affect either the extent or the duration of HSP synthesis in $S$. cerevisiae. They were not repeated on Sch. pombe strains JV66 and 972 because growth of these strains in minimal medium is severely restricted by their adenine auxotrophy even in the presence of exogenous adenine (Ulaszewski et al., 1987).

\section{Influence of pma1.1 on ethanol tolerance, osmotolerance and tolerance of ultraviolet irradiation}

The pmal.1 mutations of $S$. cerevisiae and Sch. pombe increased tolerance of brief exposures to high ethanol and high salt concentrations, and decreased tolerance of ultraviolet irradiation (Fig. 4). Similar results were obtained with $S$. cerevisiae pma1.2, pmal.3 and pmal.4 (data not shown).

\section{Discussion}

S. cerevisiae pma1.1, pmal.2, pmal.3 and pma1.4, and Sch. pombe pma1.1, were isolated as spontaneous mutants showing resistance to Dio-9, a non-specific inhibitor of plasma-membrane ATPase (Ulaszewski et al., 1983, 1986). They exhibit several similar changes in the in vitro properties of plasma-membrane ATPase, which is why they were investigated in parallel in this study. These changes include: (i) a lower specific activity; (ii) a modified $K_{\mathrm{m}}$ for MgATP; and (iii) strong resistance to vanadate (Ulaszewski et al., 1983, 1987). The Sch. pombe pmal.1 mutation corresponds to a single amino acid substitution in the ATPase, namely Gly to Asp at residue 268 (Ghislain et al., 1987).
These mutants were used to obtain evidence as to whether plasma-membrane ATPase action exerts a major influence on tolerances to elevated temperatures and other forms of stress. The fact that mutation to Dio-9 resistance causes identical changes to several tolerances in two very distantly related species shows that the profound metabolic changes that ensue from alteration to plasma-membrane ATPase activity are an important determinant of these tolerance levels. Also, protein pulse-labelling in $S$. cerevisiae indicated that pmal.1 can affect the extent and duration of HSP synthesis induced by the heat-shock response.

When $S$. cerevisiae or $S c h$. pombe cells actively growing at $25^{\circ} \mathrm{C}$ are shifted to $48^{\circ} \mathrm{C}$ there is rapid protein synthesis arrest; no HSPs are synthesized and these cells, uninduced for thermotolerance, quickly die. Pulselabelling studies have shown that neither yeast can synthesize HPSs above $42-43^{\circ} \mathrm{C}$ (Piper et al., 1986; also unpublished observations). At $48^{\circ} \mathrm{C}$ pmal.1 conferred higher thermotolerance (Figs $1 a$ and $2 a$ ). This result was not entirely unexpected for $S$. cerevisiae, since pmal.1 causes slightly slower growth of prototrophic strains on YEPD, and thermotolerance levels are generally thought to be inversely related to the growth rate of this organism (Iida \& Yahara, 1984; Iida, 1988). Figs $1(b)$ and 2(b) show survival of the same $S$. cerevisiae and $S \mathrm{ch}$. pombe cultures after they had been shifted from $25^{\circ} \mathrm{C}$ to $38^{\circ} \mathrm{C}$ for $40 \mathrm{~min}$ and then exposed to a considerably higher temperature $\left(52{ }^{\circ} \mathrm{C}\right)$. This non-acute $38^{\circ} \mathrm{C}$ heat shock induces the synthesis of heat shock proteins, and causes a marked elevation of thermotolerance (for evidence of this in $S$. cerevisiae see Piper et al., 1986, 1987, 1988). However, the increase in this thermotolerance was less for pmal.1 than for wild-type cells given the same heat shock, in both S. cerevisiae and Sch. pombe (Figs 1 and 2). As a result, pmal.1 cells were killed more rapidly in such cultures induced for thermotolerance, the converse of the situation found in the uninduced cultures. Both this observation and the reduction in HSP synthesis (Fig. $3 a$ ) are consistent with pmal.l causing a partial suppression of the heat-shock response normally caused by a $25-$ $38^{\circ} \mathrm{C}$ temperature shift. Important considerations here may be the extent of cytoplasmic acidification that accompanies heat shock (Weitzel et al., 1987) and the rate at which it is counteracted by plasma-membrane ATPase action. Since the pmal.1 mutant of Sch. pombe maintains a smaller transmembrane $\mathrm{H}^{+}$gradie:it than wild-type $S c h$. pombe, with a cytoplasmic pH 0.4 units lower (Ulaszewski et al., 1987), there are grounds for expecting smaller decreases in cytoplasmic $\mathrm{pH}$ with heat-shock stress in this mutant. This may in turn lead to a reduced heat-shock response. The thermal stability of the ATPase must also be an important factor. Although the wild-type enzyme is the more active under most assay 
conditions, in vitro studies have shown the $S$. cerevisiae pmal.1 enzyme to be less prone to inactivation at $50^{\circ} \mathrm{C}$ (Ulaszewski et al., 1983).

The pmal.1 mutants of S. cerevisiae and Sch. pombe exhibit greater tolerances of ethanol and high salt than the wild-type (Fig. 4). Low cyclic AMP levels in $S$. cerevisiae also cause higher ethanol tolerance (Iida, 1988). Ethanol diffuses rapidly into $S$. cerevisiae cells (Guijarro \& Lagunas, 1984) and affects membrane order, as shown by Walker-Caprioglio \& Parks (1987), using the lipophilic probe 1,6-diphenyl-1,3,5 hexatriene. This change in membrane order causes enhanced proton influx (Leao \& VanUden, 1985), and ethanol therefore has marked effects on the maintenance of cytoplasmic $\mathrm{pH}$ and $\mathrm{H}^{+}$-coupled transport of solutes across the plasma membrane. In contrast to ethanol tolerance, osmotolerance may primarily reflect intracellular levels of osmoregulatory solutes. Fungi that grow in media of high osmotic strength synthesize polyols (e.g. glycerol, arabitol) at high levels; these increase osmotolerance by functioning as compatible solutes. Their levels change with growth state and are major determinants of osmoregulation. Glycerol, probably the most important osmotic effector in exponentially-growing salt-stressed yeast (Reed et al., 1987), is made at higher levels in yeast exposed to hypertonic media (Maiorella et al., 1984).

The reduction in plasma-membrane ATPase activity due to pmal.1 causes a slight reduction in growth rate on rich medium and a considerable reduction in growth on minimal medium containing ammonia as nitrogen source. Amino-acid and purine auxotrophies reduce the growth rate still further (Ulaszewski et al., 1987). Physiological changes due to adaptation of pmal.1 cells to slower growth presumably cause some of the tolerance effects observed in this study, but may not be the only cause of the observed differences. Thus pmal.1 might even allow higher plasma-membrane ATPase activity under high-ethanol or dehydrating conditions, just as it renders this enzyme less susceptible to vanadate inhibition (Ulaszewski et al., 1983). The available evidence highlights the need to relate tolerance measurements to other physiological studies (e.g. those measuring intracellular $\mathrm{pH}$ shifts under stress conditions) and in vitro studies of plasma-membrane ATPase action. However, the results with pma1.1 mutant strains described in this paper show that plasma-membrane ATPase action cannot be ignored as a factor affecting tolerances of a variety of potentially cytotoxic agents (Figs 1, 2 and 4) and as a determinant of the extent and duration of at least one inducible stress response (Fig. 3).

We thank A. Goffeau for providing strains. This work was supported by the Central Research Fund of London University, and the award of a SERC Studentship to B.P.

\section{References}

Aaronson, L. R., Hager, K. M., Davenport, J. W., Mandala, S. M., Chang, A., Speicher, D. W. \& Slayman, C. W. (1988). Biosynthesis of the plasma membrane $\mathrm{H}^{+}$-ATPase of Neurospora crassa. Journal of Biological Chemistry 263, 14552-14558.

ANanthan, J., Goldberg, A. L. \& Voellmy, R. (1986). Abnormal proteins serve as eukaryotic stress signals and trigger the activation of heat shock genes. Science 232, 522-524.

BoUCHERIE, H. (1985). Protein synthesis during transition and stationary phase under glucose limitation in Saccharomyces cerevisiae. Journal of Bacteriology 161, 385-392.

Boutry, M., MiChELET, B. \& GofFEAU, A. (1989). Molecular cloning of a family of plant genes encoding a protein homologous to plasma membrane $\mathrm{H}^{+}$-translocating ATPase. Biochemical and Biophysical Research Communications 162, 567-574.

CraIG, E. A. (1986). The heat shock response. CRC Critical Reviews in Biochemistry 18, 239-280.

Curran, B., Davies, M. W., Hirst, K., Seward, K. \& Piper, P. W. (1988). Genes transcribed efficiently both before and after heat shock: their promoter operation and roles in stress protection. Yeast 4, S324.

Eraso, P. \& Gancedo, C. (1987). Activation of yeast plasma membrane ATPase by acid pH during growth. FEBS Letters 224 , 187-192.

Eraso P., Mazón, M. J. \& Gancedo, J. M. (1987). Internal acidification and cAMP increase are not correlated in Saccharomyces cerevisiae. European Journal of Biochemistry 165, 671-674.

Ghislain, M., Schlesser, A. \& Goffeau, A. (1987). Mutation of a conserved glycine residue modifies the vanadate sensitivity of the plasma membrane $\mathrm{H}^{+}$-ATPase from Schizosaccharomyces pombe. Journal of Biological Chemistry 262, 17549-17555.

GuiJarRo, J. M. \& Lagunas, R. (1984). Saccharomyces does not accumulate ethanol against a concentration gradient. Journal of Bacteriology 160, 874-878.

Harper, J. F., Surowy, T. K. \& Sussman, M. R. (1989). Molecular cloning and sequence of cDNA encoding the plasma membrane proton pump ( $\mathrm{H}^{+}-$ATPase $)$of Arabidopsis thaliana. Proceedings of the National Academy of Sciences of the United States of America 86, 1234-1238.

IIDA, H. (1988). Multistress resistance of Saccharomyces cerevisiae is generated by insertion of retrotransposon $\mathrm{Ty}$ into the $5^{\prime}$ noncoding region of the adenylate cyclase gene. Molecular and Cellular Biology 8, 5555-5560.

IIDA, H. \& YAHARA, Y. (1984). Durable synthesis of high molecular weight heat shock proteins in $\mathrm{G}_{0}$ cells of yeast and other eukaryotes. Journal of Cell Biology 99, 199-207.

LEAO, C. \& VANUDEN, N. (1985). Effects of ethanol and other alkanols on the temperature relations of glucose transport and fermentation in Saccharomyces cerevisiae. Applied Microbiology and Biotechnology 22, 359-363.

LindQuist, S. \& Craig, E. A. (1988). The heat shock proteins. Annual Review of Genetics 55, 1151-1191.

Maiorella, B. L., Blanch, H. W. \& Wilke, C. R. (1984). Feed component inhibition in ethanolic fermentation by Saccharomyces cerevisiae. Biotechnology and Bioengineering 26, 1155-1166.

Pardo, J. M. \& Serrano, R. (1989). Structure of a plasma membrane $\mathrm{H}^{+}$-ATPase gene from the plant Arabidopsis thaliana. Journal of Biological Chemistry 264, 8557-8562.

Pelham, H. R. B. (1987). Heat shock proteins - coming in from the cold. Nature, London 332, 776-777.

Piper, P. W., Curran, B., Davies, M. W., Lockheart, A. \& Reid, G. (1986). Transcription of the phosphoglycerate kinase gene of Saccharomyces cerevisiae increases when fermentative cultures are stressed by heat shock. European Journal of Biochemistry 161, 525-531.

Piper, P. W., Davies, M. W., Curran, B., Lockheart, A., Spalding, A. \& TUITE, M. F. (1987). The influence of cell ploidy on the thermotolerance of Saccharomyces cerevisiae. Current Genetics 11, 595-598.

Piper, P. W., Curran, B., Davies, M. W., Hirst, K., Lockheart A. \& SEWARD, K. (1988). Catabolite control of the elevation of PGK 
mRNA levels by heat shock in Saccharomyces cerevisiae. Molecular Microbiology 2, 353-361.

Reed, R. H., Chudek, J. A., Foster, R. \& Gadd, G. M. (1987). Osmotic significance of glycerol accumulation in exponentially growing yeasts. Applied and Environmental Microbiology 53, 21192123.

SerRano, R., Kielland-Brandt, M. C. \& FinK, G. R. (1986). Yeast plasma membrane ATPase is essential for growth and has homology with $\left(\mathrm{Na}^{+}+\mathrm{K}^{+}\right), \mathrm{K}^{+-}$and $\mathrm{Ca}^{2+-A T P a s e s . ~ N a t u r e, ~ L o n d o n ~ 319, ~ 689-~}$ 693.

ShIN, D.-Y., Matsumoto, K., IIDA, H., Uno, I. \& IshikaWa T. (1987). Heat shock response of Saccharomyces cerevisiae mutants altered in cyclic AMP-dependent protein phosphorylation. Molecular and Cellular Biology 7, 244-250.

Ulaszewski, S., Grenson M. \& Goffeau, A. (1983). Modified plasma membrane ATPase in mutants of Saccharomyces cerevisiae. European Journal of Biochemistry 130, 235-239.
Ulaszewski, S., Coddington, A. \& Goffeau, A. (1986). A new mutation for multiple drug resistance and modified plasma membrane ATPase activity in Schizosaccharomyces pombe. Current Genetics 10, 359-364.

Ulaszewski, S., Van Herck, J. C., Dufour, J. P., Kulpa, J., NieUWENHUIS, B. \& GofFEAU, A. (1987). A single mutation confers vanadate resistance to the plasma membrane $\mathrm{H}^{+}$-ATPase from the yeast Schizosaccharomyces pombe. Journal of Biological Chemistry 262, 223-228.

Wal KeR-CAPRIOGLIO, H. M. \& PARKS, L. W. (1987). Autoconditioning factor relieves ethanol-induced growth inhibition of Saccharomyces cerevisiae. Applied and Environmental Microbiology 53, 33-35.

Weitzel, G., Pilatus, U. \& Rensing, L. (1987). The cytoplasmic pH, ATP content and total protein synthesis rate during heat-shock protein inducing treatments in yeasts. Experimental Cell Research 170, 64-79. 